\title{
Article \\ A Single Crystal Hybrid Ligand Framework of Copper(II) with Stable Intrinsic Blue-Light Luminescence in Aqueous Solution
}

\author{
Suwitra Charoensuk ${ }^{1}$, Jing Tan ${ }^{2}$, Mohini Sain ${ }^{2, *}$ and Hathaikarn Manuspiya ${ }^{1,3, *}$ \\ 1 The Petroleum and Petrochemical College, Chulalongkorn University, Bangkok 10330, Thailand; \\ suwitra.c@gmail.com \\ 2 Center for Biocomposites and Biomaterials Processing, Department of Mechanical and Industrial Engineering, \\ University of Toronto, Toronto, ON M5S 3B3, Canada; jingbuct.tan@utoronto.ca \\ 3 Center of Excellence in Petrochemical and Materials Technology, Bangkok 10330, Thailand \\ * Correspondence: m.sain@utoronto.ca (M.S.); hathaikarn.m@chula.ac.th (H.M.)
}

check for updates

Citation: Charoensuk, S.; Tan, J.; Sain, M.; Manuspiya, H. A Single Crystal Hybrid Ligand Framework of Copper(II) with Stable Intrinsic Blue-Light Luminescence in Aqueous Solution. Nanomaterials 2021, 11, 2281. https://doi.org/10.3390/ nano11092281

Academic Editors: Sotirios Baskoutas and Marcin Runowski

Received: 30 July 2021

Accepted: 26 August 2021

Published: 2 September 2021

Publisher's Note: MDPI stays neutral with regard to jurisdictional claims in published maps and institutional affiliations.

Copyright: (c) 2021 by the authors. Licensee MDPI, Basel, Switzerland. This article is an open access article distributed under the terms and conditions of the Creative Commons Attribution (CC BY) license (https:// creativecommons.org/licenses/by/ $4.0 /)$.

\begin{abstract}
Single-crystal solid-liquid dual-phase hybrid organic-inorganic ligand frameworks with reversible sensing response facilitated by external stimuli have received significant attention in recent years. This report presents a significant leap in designing electronic structures that display reversible dual-phase photoluminescence properties from single-crystal hybrid ligand frameworks. Three-dimensional $\mathrm{Cu}\left(\mathrm{C}_{3} \mathrm{~N}_{2} \mathrm{H}_{4}\right)_{4} \mathrm{Cl}_{2}$ complex frameworks were formed through the intermolecular hydrogen bonding and $\pi \cdots \pi$ stacking supramolecular interactions. The absorption band peaks at $627 \mathrm{~nm}$ were assigned to $\mathrm{d}-\mathrm{d}$ transition showing $10 \mathrm{Dq}=15,949 \mathrm{~cm}^{-1}$ and crystal field stabilization energy $(\mathrm{CFSE})=0.6 \times 10 \mathrm{Dq}=114.4 \mathrm{kJmol}^{-1}$, while the ligand-to-metal charge transfer $(\mathrm{LMCT})$ of complexes was displayed at $292 \mathrm{~nm}$. The intense luminescence band results from LMCT present at $397 \mathrm{~nm}$. Considering its structure, air stability, framework forming and stable luminescence in aqueous solution, the $\mathrm{Cu}\left(\mathrm{C}_{3} \mathrm{~N}_{2} \mathrm{H}_{4}\right)_{4} \mathrm{Cl}_{2}$ complex shows potential for luminescence $\mathrm{Cu}$-based sensors using emission intensity to detect heavy metal ion species.
\end{abstract}

Keywords: copper coordination complexes; 3D network complexes; crystal structure; electronic structure; luminescence

\section{Introduction}

Over the past decade, the study of copper(II) coordination complexes has been rapidly developing due to their structural variety and wide range of potential applications such as catalysis [1], gas absorption [2], photocatalysis [3], electrocatalytic [4], magnetic [5], perovskite solar cell [6], luminescence [7], etc. The copper(II) ion, paramagnetic $\mathrm{d}^{9}$ configuration, enables the generated strong metal-ligand (M-L) bonding through hard-soft acid-base (HSAB) principles [8]. Many copper(II) coordination complex geometry with different coordination numbers have been reported, such as distorted tetrahedral or square planar [9], tetragonal bipyramidal [10], square pyramidal [11] and distorted octahedral [12] according to a typical Jahn-Teller effect [13]. The Jahn-Teller effect strongly results in the electron distribution that affects the arrangement of atoms in crystal structure. Thus, Jahn-Teller distortions prompt formation of copper(II) coordination complexes leading to the different $\mathrm{M}-\mathrm{L}$ bond geometries mentioned above [14].

Among those of N-donor or base ligands, the N-heterocyclic imidazole (Im) coordination ligands (M-L) have gained considerable attention as the formation of threedimensional network complex structures through intermolecular hydrogen bonds and $\pi \cdots \pi$ supramolecular interactions have various applications. The imidazole ligand is generally considered to be a moderate s-donor and weak $\pi$-acceptor, as well as strong ligands for copper(II). In the case of tetragonal geometry, imidazole coordinates to copper(II) coupling $\mathrm{Cu}\left(\mathrm{C}_{3} \mathrm{~N}_{2} \mathrm{H}_{4}\right)_{4} \mathrm{Cl}_{2}$ similar to pyridine with the occupying coplanar position corresponding to metal ion, while the metal-halide $(\mathrm{M}-\mathrm{X})$ bond locates on the axial axis of the co- 
ordination complex. Chlorotetrakis(imidazole) copper(II) chloride, $\mathrm{Cu}\left(\mathrm{C}_{3} \mathrm{~N}_{2} \mathrm{H}_{4}\right)_{4} \mathrm{Cl}_{2}$, was synthesized by $\mathrm{Li}$ and co-workers [15], using $\mathrm{CuCl}_{2} \cdot 2 \mathrm{H}_{2} \mathrm{O}$ and imidazole in methanol, and the obtained crystals can be described as having a monoclinic crystal structure and space group P2 ${ }_{1} / \mathrm{n}$ with unit cell parameters, namely a $=8.8662(3), \mathrm{b}=13.3199(4), \mathrm{c}=13.3190(4) \AA$ and $\beta=90.0420(10)^{\circ}$, different than the report from Jian et al. [16]. Jian and co-workers reported that the coordination complexes belong to the monoclinic space group $\mathrm{P}_{1} / \mathrm{c}$ and show different unit cell parameters: $\mathrm{a}=13.909(3), \mathrm{b}=8.8933(18), \mathrm{c}=15.086(7) \AA$ and $\beta=118.32(2)^{\circ}$. The most common way to understand the electronic structure of the copper coordination network is UV-Vis spectra analysis corresponding to the molecular orbital energy diagram. The spectra bands can determine the $\mathrm{d}-\mathrm{d}$ transition of the metal center atom and charge transfer (CT) in metal and ligand bonding.

This research embarks on the study of the electronic structure of the copper(II) coordination complex and new findings on its luminescent properties for electrocatalytic process with in situ sensing along with other types of sensing in smart materials, such as actuators. Furthermore, we have reported the luminescence of $\mathrm{Cu}\left(\mathrm{C}_{3} \mathrm{~N}_{2} \mathrm{H}_{4}\right)_{4} \mathrm{Cl}_{2}$ complexes characterized by fluorescent spectroscopy. The results contribute that the orbitals from ligand charge transfer play a crucial role in the origin of luminescence at $397 \mathrm{~nm}$ emission wavelength observed by excitation wavelength equal to $330 \mathrm{~nm}$.

\section{Materials and Methods}

\subsection{Materials}

Copper (II) chloride $\left(\mathrm{CuCl}_{2} .2 \mathrm{H}_{2} \mathrm{O}, 99.9 \%\right.$, Aldrich, Saint Louis, MO, USA), imidazole $\left(\mathrm{C}_{3} \mathrm{~N}_{2} \mathrm{H}_{4}, 99.5 \%\right.$, Aldrich, Saint Louis, MO, USA), absolute methanol $\left(\mathrm{CH}_{3} \mathrm{OH}, 99 \%\right)$ and formic acid ( $\mathrm{HCOOH}, 99 \%)$ were commercially available and used as purchased, without further purification.

\subsection{Synthetic Procedure of Copper Coordinate Complexes}

The synthetic route used here is an adaptation of the previously reported method for the preparation of the $\left(\mathrm{C}_{3} \mathrm{~N}_{2} \mathrm{H}_{5}\right)\left[\mathrm{Mn}\left(\mathrm{HCOO}_{3}\right)\right]$ compounds [17] in order to accomplish similar perovskite structure by replacing $\mathrm{Mn}^{2+}$ to $\mathrm{Cu}^{2+}$. In a typical experiment, $5 \mathrm{~mL}$ of methanol solution of imidazole and formic acid were placed at the bottom of vial glass. Upon the $\mathrm{HCOOH}-\mathrm{C}_{3} \mathrm{~N}_{2} \mathrm{H}_{4}$ solution, $2 \mathrm{~mL}$ of methanol was carefully added, followed by carefully layering $8 \mathrm{~mL}$ of $\mathrm{CuCl}_{2} \cdot 2 \mathrm{H}_{2} \mathrm{O}$ solution by using mol ratio 3:1:3 of $\mathrm{C}_{3} \mathrm{~N}_{2} \mathrm{H}_{4}: \mathrm{CuCl}_{2} \cdot 2 \mathrm{H}_{2} \mathrm{O}: \mathrm{HCOOH}$. The vial was sealed and kept undisturbed at $50{ }^{\circ} \mathrm{C}$. The blue crystal appeared after several days. They were collected, washed with ethanol and dried at room temperature. All are air stable. The unexpected reaction was assembled. The obtained copper coordination complexes had not formed structure with formate like $\left(\mathrm{C}_{3} \mathrm{~N}_{2} \mathrm{H}_{5}\right)\left[\mathrm{Mn}(\mathrm{HCOO})_{3}\right]$ as mentioned above but bonded to imidazole and chloride instead shown as $\mathrm{Cu}\left(\mathrm{C}_{3} \mathrm{~N}_{2} \mathrm{H}_{4}\right)_{4} \mathrm{Cl}_{2}$ chemical formula. For the $\left(\mathrm{C}_{3} \mathrm{~N}_{2} \mathrm{H}_{5}\right)\left[\mathrm{Mn}(\mathrm{HCOO})_{3}\right]$ structure, $\mathrm{Mn}^{2+}$ as hard metal and therefore form stronger complexes with oxygen donors than $\mathrm{N}$-pyridine, according to the hard-soft acid-base (HSAB) principle. The formate ligands also act as bridging $\mathrm{Mn}^{2+}$ and form $\mathrm{ABO}_{3}$ perovskite framework and imidazolium ion located in cavities by $\mathrm{NH} \cdots \mathrm{O}$ hydrogen bond interaction. On the other hand, the $\mathrm{N}$-donor of imidazole is the borderline base and prefers to form stronger complexes with borderline acid $\mathrm{Cu}^{2+}$, leading to obtain $\mathrm{Cu}\left(\mathrm{C}_{3} \mathrm{~N}_{2} \mathrm{H}_{4}\right)_{4} \mathrm{Cl}_{2}$ coordination complexes.

\subsection{Characterizations}

\subsubsection{Single-Crystal X-ray Crystallography (SC-XRD)}

The single-crystals were analyzed with Mo K $\alpha(\lambda=0.71073 \AA)$ on a 'Bruker APEX-II $\mathrm{CCD}^{\prime}$ diffractometer. The crystals were kept at $273 \mathrm{~K}$ during data collection. The chemical structure was determined by using the Olex2 program where charge flipping was used, as well as XH refinement packaging, using CGLS minimization. 


\subsubsection{X-ray Diffraction (XRD)}

XRD pattern were collected by using a Rigaku model Smart Lab 4800 diffractometer with a $\mathrm{Cu} \mathrm{K} \alpha$ radiation wavelength $(\lambda=1.54 \AA)$, generated at a voltage of $40 \mathrm{kV}$ and a filament emission of $30 \mathrm{~mA}$. Sample powder was scanned from the $2 \theta=10$ to $40^{\circ}$ range at a scan speed of $2^{\circ} / \mathrm{min}$ and a scan step of $0.02^{\circ}$ at room temperature.

\subsubsection{X-ray Photoelectron Spectroscopy}

The binding energy of complexes were measured by XPS (Kratos Axis Ultra DLD) with a monochromatic $\mathrm{Al} \mathrm{K} \alpha$ as an X-ray source (anode $\mathrm{HT}=15 \mathrm{kV}$ ) and energy dispersive X-ray analysis (EDX, JSM-7610 F, JEOL, Akishima, Tokyo, JAPAN). The depth of penetration of XPS is $10 \mathrm{~nm}$. Data evaluation was performed by using CasaXPS.

\subsubsection{Element Analysis}

$\mathrm{CHN}$ analysis was performed to confirm the elemental composition: $\mathrm{C}, \mathrm{H}$ and $\mathrm{N}$ by TruSpec Micro CHNS modal. For $\mathrm{Cu}$ and $\mathrm{Cl}$ composition, the crystal was detected by Electron Probe-Micro analyzer at Earth Science Centre, University of Toronto. $\mathrm{Cu}\left(\mathrm{C}_{3} \mathrm{~N}_{2} \mathrm{H}_{4}\right)_{4} \mathrm{Cl}_{2}$ was found to be $35.14 \% \mathrm{C}, 3.94 \% \mathrm{H}, 27.32 \% \mathrm{~N}, 15.49 \% \mathrm{Cu}$ and $18.10 \% \mathrm{Cl}$, similar to the expected $35.43 \% \mathrm{C}, 3.97 \% \mathrm{H}, 27.55 \% \mathrm{~N}, 15.62 \% \mathrm{Cu}$ and $17.43 \% \mathrm{Cl}$.

\subsubsection{Fourier Transform Infrared Spectroscopy (FTIR)}

$\mathrm{Cu}\left(\mathrm{C}_{3} \mathrm{~N}_{2} \mathrm{H}_{4}\right)_{4} \mathrm{Cl}_{2}$ coordination crystals were examined by using an ATR Nicolet iD7 FTIR spectrometer. All spectra were scanned between 4000 and $400 \mathrm{~cm}^{-1}$, with 128 convolutions at a resolution of $4 \mathrm{~cm}^{-1}$.

\subsubsection{Thermal Analysis}

Thermogravimetric analyses were performed by using a TGA Q500 (TA Instruments, Newcastle, DE, USA). The procedures were conducted under nitrogen with flow rate $60 \mathrm{~mL} / \mathrm{min}$, following. Crystal samples of $10-15 \mathrm{mg}$ was placed on a platinum pan, where a temperature range of $25-800^{\circ} \mathrm{C}$ was reached, with a heating ramp of $5{ }^{\circ} \mathrm{C} / \mathrm{min}$. Samples were studied for mass loss curves.

\subsubsection{UV-Vis and Fluorescent Spectrophotometer}

The UV-Vis spectra were carried in PerkinElmer, Lambda 35 UV-Vis spectrophotometer in the wavelength window of $200-800 \mathrm{~nm}$. The $\mathrm{Cu}\left(\mathrm{C}_{3} \mathrm{~N}_{2} \mathrm{H}_{4}\right)_{4} \mathrm{Cl}_{2}$ crystals were dissolved in deionized water and sonicated for $15 \mathrm{~min}$ before measuring. Photoluminescence (PL) was measured by using the fluorescent spectrometer (Fluorolog-3, Horiba, Edison, NJ, USA) of solution.

\section{Results and Discussion}

\subsection{Molecular Structure and Crystallography Data of [Cu(II) $\left.\left(\mathrm{C}_{3} \mathrm{~N}_{2} \mathrm{H}_{4}\right)_{4} \mathrm{Cl}\right] \mathrm{Cl}$, or $\left[\mathrm{Cu}(\mathrm{II}) \mathrm{Im}_{4} \mathrm{Cl}\right] \mathrm{Cl}$, Coordination Framework}

Hybrid organic-inorganic ligand frameworks of $\left[\mathrm{Cu}(\mathrm{II})\left(\mathrm{C}_{3} \mathrm{~N}_{2} \mathrm{H}_{4}\right)_{4} \mathrm{Cl}\right] \mathrm{Cl}$ were synthesized and analyzed by element analysis and single-crystal and powder X-ray diffractions. The results of the chemical reaction showed that imidazole was protonated then formed square pyramidal $\mathrm{C}_{4 \mathrm{v}}$ of $\left[\mathrm{CuIm}{ }_{4} \mathrm{Cl}\right]^{+}$coordination complexes similar to pyridine ligands [18]. According to our results, crystallography data of $\left[\mathrm{Cu}(\mathrm{II})\left(\mathrm{C}_{3} \mathrm{~N}_{2} \mathrm{H}_{4}\right)_{4} \mathrm{Cl}\right] \mathrm{Cl}$ shows that complexes crystallize in space group $\mathrm{P} 2{ }_{1} / \mathrm{n}$ monoclinic system with similar unit cell parameters to those reported by Li et al. [15] and Otieno et al. [19]. The unit cell parameters of the obtained crystals were $\mathrm{a}=8.8707(4), \mathrm{b}=13.3224(8), \mathrm{c}=13.925(6) \AA, \alpha, \gamma=90$ and $\beta=90.094(2)$. Table 1 exhibits all the crystallography data of $\left[\mathrm{Cu}(\mathrm{II})\left(\mathrm{C}_{3} \mathrm{~N}_{2} \mathrm{H}_{4}\right)_{4} \mathrm{Cl}\right] \mathrm{Cl}$, a hybrid organic-inorganic ligand complex which crystallizes in space group $\mathrm{P} 2_{1} / \mathrm{n}$ monoclinic system similar to those in previous works. SC-XRD revealed that the blue plate crystals, $\left[\mathrm{Cu}(\mathrm{II})\left(\mathrm{C}_{3} \mathrm{~N}_{2} \mathrm{H}_{4}\right)_{4} \mathrm{Cl}\right] \mathrm{Cl}$, exhibit a square pyramidal coordination of $\mathrm{Cu}(\mathrm{II})$ as metal center atom. Four equatorial $\mathrm{N}$ atoms of imidazole ligands were linked by copper(II) to 
form a base of a square pyramid, and copper(II) also bonded one of the chlorine atoms perpendicular to the plane located at the apex of the pyramid.

Table 1. Crystallography data for Chloridotetrakis(imidazole)copper(II) chloride, $\left[\mathrm{Cu}(\mathrm{II})\left(\mathrm{C}_{3} \mathrm{~N}_{2} \mathrm{H}_{4}\right)_{4} \mathrm{Cl}\right] \mathrm{Cl}$.

\begin{tabular}{|c|c|}
\hline \multicolumn{2}{|c|}{ Crystallography Data } \\
\hline Empirical formula & $\mathrm{C}_{12} \mathrm{H}_{16} \mathrm{~N}_{8} \mathrm{Cl}_{2} \mathrm{Cu}$ \\
\hline Formula weight & 406.77 \\
\hline Temperature/K & 273.15 \\
\hline Crystal system & monoclinic \\
\hline Space group & $\mathrm{P} 2{ }_{1} / \mathrm{n}$ \\
\hline $\mathrm{a} / \AA$ & $8.8707(4)$ \\
\hline $\mathrm{b} / \AA$ & $13.3224(8)$ \\
\hline $\mathrm{c} / \AA$ & $13.9250(6)$ \\
\hline$\alpha /^{\circ}$ & 90 \\
\hline$\beta /{ }^{\circ}$ & $90.094(2)$ \\
\hline$\gamma /{ }^{\circ}$ & 90 \\
\hline Volume $/ \AA^{3}$ & $1645.64(14)$ \\
\hline Z & 4 \\
\hline$\rho_{\text {calc }} \mathrm{g} / \mathrm{cm}^{3}$ & 1.6417 \\
\hline$\mu / \mathrm{mm}^{-1}$ & 1.663 \\
\hline $\mathrm{F}(000)$ & 830.7 \\
\hline Crystal size $/ \mathrm{mm}^{3}$ & $0.42 \times 0.4 \times 0.32$ \\
\hline Radiation & $\operatorname{MoK} \alpha(\lambda=0.71073)$ \\
\hline $2 \Theta$ range for data collection $/{ }^{\circ}$ & 5.44 to 61.14 \\
\hline Index ranges & $-10 \leq \mathrm{h} \leq 12,-19 \leq \mathrm{k} \leq 6,-19 \leq 1 \leq 15$ \\
\hline Reflections collected & 7881 \\
\hline Independent reflections & $4439\left[R_{\text {int }}=0.0395, R_{\text {sigma }}=0.0566\right]$ \\
\hline Data/restraints/parameters & $4439 / 0 / 217$ \\
\hline Goodness-of-fit on $\mathrm{F}^{2}$ & 1.072 \\
\hline Final $R$ indexes $[I \geq 2 \sigma(I)]$ & $\mathrm{R}_{1}=0.0359, \mathrm{w} \mathrm{R}_{2}=0.0868$ \\
\hline Final $\mathrm{R}$ indexes [all data] & $\mathrm{R}_{1}=0.0520, \mathrm{w} \mathrm{R}_{2}=0.0959$ \\
\hline Largest diff. peak/hole/e $\AA^{-3}$ & $0.58 /-0.62$ \\
\hline
\end{tabular}

The square pyramid weakly bound axial chlorides as counterions through hydrogen intermolecular interactions [15]. There are two weak hydrogen bonds, $\mathrm{C} 1-\mathrm{H} 1 \cdots \mathrm{Cl}(2)$ and C9- $\mathrm{H} 12 \cdots \mathrm{Cl}(2)$, which link the discrete $\left[\mathrm{Cu}(\mathrm{II})\left(\mathrm{C}_{3} \mathrm{~N}_{2} \mathrm{H}_{4}\right)_{4} \mathrm{Cl}\right]^{+}$cation and $\mathrm{Cl}^{-}$counter anion in an asymmetrical unit as presented in the crystal structure illustrated in Figure 1.
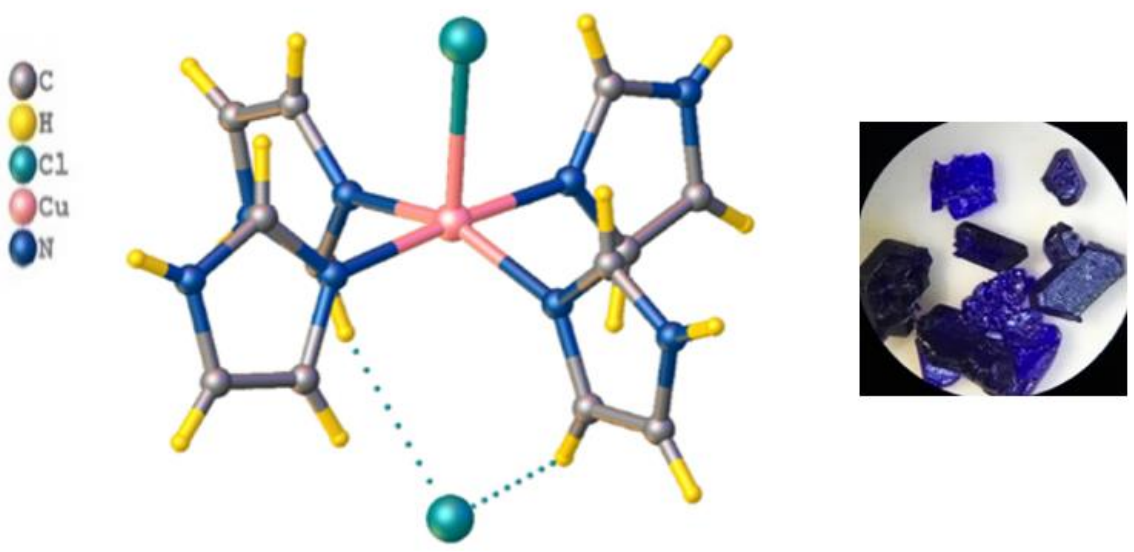

Figure 1. Coordination environment about the $\mathrm{Cu}(\mathrm{II})$ metal center of square pyramidal $\left[\mathrm{Cu}(\mathrm{II})\left(\mathrm{C}_{3} \mathrm{~N}_{2} \mathrm{H}_{4}\right)_{4} \mathrm{Cl}\right] \mathrm{Cl}$ coordination complex showing hydrogen bonding as dashed line and its optical image.

The intermolecular hydrogen bonds consequently resulted in a connected threedimensional network with $\mathrm{N}-\mathrm{H} \cdots \mathrm{Cl}$ and $\mathrm{C}-\mathrm{H} \cdots \mathrm{Cl}$ interactions (Figure 2). Another 
significant 3D network, forming the $\pi \cdots \pi$ supramolecular interactions between neighboring imidazole ligands, plays a role in the packing system, as shown in Figure 2. The $\pi \cdots \pi$ interactions were reported by measuring the distance between one centroid and the next centroid in an imidazole ring $(\mathrm{Ct} \cdots \mathrm{Ct})$. All geometry parameters of intermolecular interactions including angles and distances are displayed in Supplementary Materials Table S1.
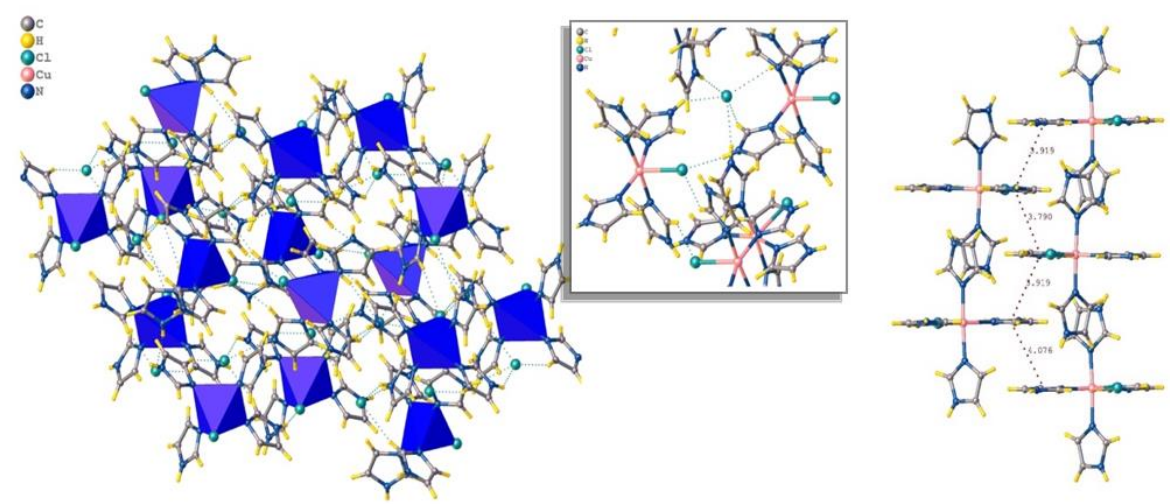

Figure 2. A continuous 3D of copper hybrid organic-inorganic ligand frameworks showing the intermolecular interactions of hydrogen bonding and $\pi \cdots \pi$ stacking.

Furthermore, the crystal structure of the $\left[\mathrm{Cu}(\mathrm{II})\left(\mathrm{C}_{3} \mathrm{~N}_{2} \mathrm{H}_{4}\right)_{4} \mathrm{Cl}\right] \mathrm{Cl}$ complexes were reversed their crystal structure as can be seen from powder $\mathrm{X}$-ray diffraction results. The simulated XRD patterns of coordination complexes can be obtained by using CIF file data from SC-XRD analysis and then simulating via Vista software. Both experimental and simulated XRD patterns show similar characteristic diffraction peaks as shown in Figure 3. Thus, the single crystalline phase of synthesized coordination complexes is confirmed.

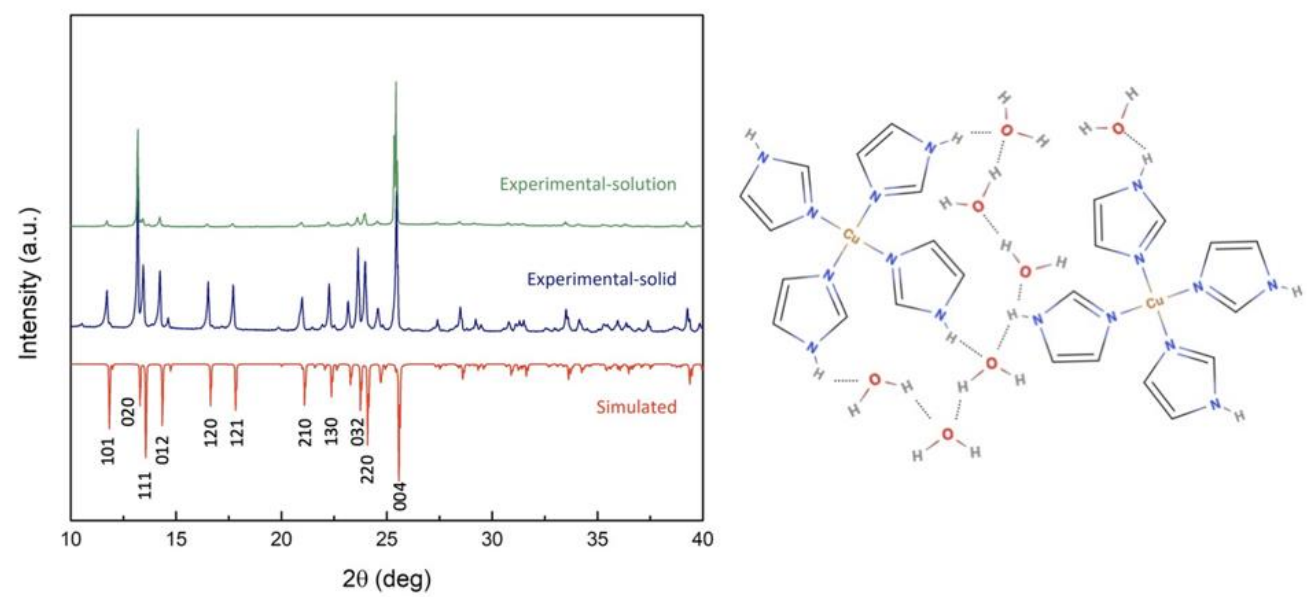

Figure 3. Simulated and experimental XRD patterns of copper(II) coordination complexes (left) and hydrogen bond interaction between coordination complexes and water molecules (right).

The XRD patterns of aqueous solution of $\left[\mathrm{Cu}\left(\mathrm{C}_{3} \mathrm{~N}_{2} \mathrm{H}_{4}\right)_{4} \mathrm{Cl}\right] \mathrm{Cl}$ coordination complexes were shown in same pattern compared with the solid pattern in Figure 3. It reveals that the $\left[\mathrm{Cu}\left(\mathrm{C}_{3} \mathrm{~N}_{2} \mathrm{H}_{4}\right)_{4} \mathrm{Cl}\right] \mathrm{Cl}$ complexes can be stable in aqueous surrounding due to intermolecular hydrogen bond between water molecules and HN-imidazole rings, as shown in Figure 3.

\subsection{Electronic Structure of $\left[\mathrm{Cu}(\mathrm{II})\left(\mathrm{C}_{3} \mathrm{~N}_{2} \mathrm{H}_{4}\right)_{4} \mathrm{Cl}\right] \mathrm{Cl}$ Coordination Complexes}

The transition metal of $\mathrm{Cu}^{2+}$ (paramagnetic $\mathrm{d}^{9}$ configuration) and the imidazole ligand could potentially form strong metal-ligand (M-L) bonding through HSAB principles [8]. The N-donor of imidazole was the borderline base and therefore form stronger complexes 
with borderline acid $\mathrm{Cu}^{2+}$. The square pyramidal copper coordination networks consisting of five-coordinate ligands in this work are not Jahn-Teller active, due to an undegenerated occupied d-orbital in their geometries [20]. The ligand field depiction (Scheme 1) implies similar $\mathrm{d} \sigma$ - and $\sigma$-levels of copper metal and imidazole ligand, respectively, which can generate $\mathrm{Cu}$-L coordinate bonding as $\sigma$-bonds. The single occupancy of the $\mathrm{dx}^{2}-\mathrm{y}^{2}\left(\mathrm{Cu}^{2+}\right)$ orbital coupling to the lone pair electron on the nitrogen of the imidazole labeled as $\sigma$-donor and the paired electrons of the antibonding of $\mathrm{dz}^{2}\left(\mathrm{Cu}^{2+}\right)$ result in increased antibonding electron density along the axial axis of $\mathrm{Cu}-\mathrm{Cl}$. It is noted that the apical elongation length of $\mathrm{Cu}-\mathrm{Cl}$ does not conform to the Jahn-Teller effect.
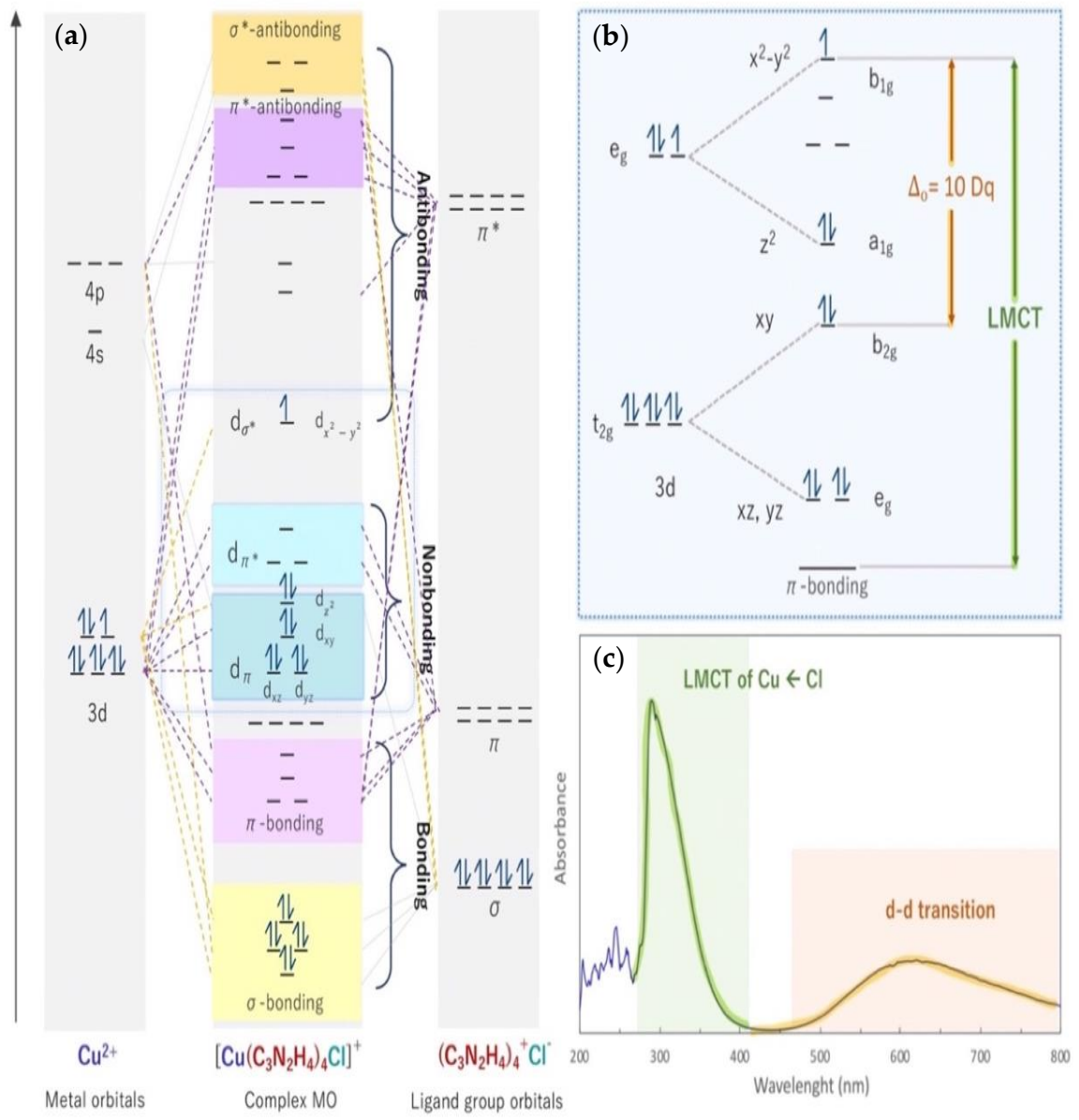

Scheme 1. The molecular orbital diagram showing ground state and excited state $\left(^{*}\right)(\mathbf{a})$, the $\mathrm{Cu}^{2+}$ electronic configuration $3 \mathrm{~d}^{9}\left(\mathrm{t}_{2 \mathrm{~g}}{ }^{6} \mathrm{e}_{\mathrm{g}}{ }^{3}\right)(\mathbf{b})$ and UV-Vis spectra (c) of copper hybrid organic-inorganic ligand frameworks.

Besides $\sigma$-bonding, $\pi$-bonding is another important interaction in coordination networks. Furthermore, the couplings of $\mathrm{d}(\mathrm{xy})\left(\mathrm{Cu}^{2+}\right)$ orbitals with ring $\pi$-orbitals and nitrogen $\pi$-donors are shown in Scheme 1. Apparently, the Chloride anion $\left(\mathrm{Cl}^{-}\right)$labeled as the $\pi$-donor ligand may donate additional electron to the d-orbital of the $\pi$-acceptor $\left(\mathrm{Cu}^{2+}\right)$ generating $\mathrm{Cu}-\mathrm{Cl}$ coordinate bonding in proper symmetric geometry. The UV-Vis spectroscopy of coordination complex was presented in Scheme 1. The electronic spectra of complexes were obtained from solute sample dissolved with water. The $\mathrm{Cu}^{2+}$ electronic configuration $3 \mathrm{~d}^{9}\left(\mathrm{t}_{2 \mathrm{~g}}{ }^{6} \mathrm{eg}^{3}\right)$, which undergoes the Jahn-Teller effect in an octahedral crystal field, agrees with the distortion octahedral geometry. The blue solution of copper(II) coordination complexes in aqueous solution shows a broad absorption band in the visible range of the spectrum at $627 \mathrm{~nm}$ which represents $\mathrm{d}-\mathrm{d}$ transitions assignable to ${ }^{2} \mathrm{E}_{\mathrm{g}} \rightarrow{ }^{2} \mathrm{~T}_{2 \mathrm{~g}}$ based on a $\mathrm{Cu}^{2+}$ central ion (Scheme 1). According to the discrete cation of coordination complexes, $\left[\mathrm{Cu}(\mathrm{II})\left(\mathrm{C}_{3} \mathrm{~N}_{2} \mathrm{H}_{4}\right)_{4} \mathrm{Cl}\right]^{+}, \mathrm{d}-\mathrm{d}$ transition shows $10 \mathrm{Dq}=15,949 \mathrm{~cm}^{-1}$ and crystal 
field stabilization energy $($ CFSE $)=0.6 \times 10 \mathrm{Dq}=114.4 \mathrm{kJmol}^{-1}$ [21]. Other absorption bands in the UV region are assigned to ligand-to-metal charge transfer (LMCT) from the highest energy ligand-localized molecular orbital to the half-occupied highest energy copper(II) $d-d$ molecular orbital [22]. The absorption bands are expected to undergo electron transition of intra-ligand $\pi \rightarrow \pi^{*}$ and ligand-to-metal charge transfer (LMCT): $\mathrm{n}_{\text {(Imidazole) }}$ $\rightarrow \mathrm{Cu}(\mathrm{II}), \pi_{1 \text { (Imidazole) }} \rightarrow \mathrm{Cu}(\mathrm{II}), \pi_{2 \text { (Imidazole) }} \rightarrow \mathrm{Cu}(\mathrm{II})$ and $\pi_{\text {Chloride }} \rightarrow \mathrm{Cu}(\mathrm{II})$. As seen in Scheme 1, The intense absorption band at $292 \mathrm{~nm}$ exhibits LMCT transition of $\mathrm{Cl}(\pi) \rightarrow$ $\mathrm{Cu}\left(\mathrm{dx}^{2}-\mathrm{y}^{2}\right)[23,24]$ resulting from the presence of a single $\mathrm{Cu}-\mathrm{Cl}$ coordination bond in aqueous solution.

\subsection{Valent State and Binding Energy of Copper Coordination Complexes}

X-ray photoelectron spectroscopy (XPS) of $\left[\mathrm{Cu}(\mathrm{II})\left(\mathrm{C}_{3} \mathrm{~N}_{2} \mathrm{H}_{4}\right)_{4} \mathrm{Cl}\right] \mathrm{Cl}$ complex powder was carried out to designate the valence states and support the presence of bonding of copper coordination complexes and $\left[\mathrm{Cu}(\mathrm{II})\left(\mathrm{C}_{3} \mathrm{~N}_{2} \mathrm{H}_{4}\right)_{4} \mathrm{Cl}\right]^{+}$ions. The wide spectrum shown in Figure 4 indicates all elements in the coordination complexes, i.e., $\mathrm{C}, \mathrm{N}, \mathrm{Cl}$ and $\mathrm{Cu}$. The highest intensity of $C 1 \mathrm{~s}$ shows three peaks due to different carbon species at 284.65, 285.84 and $288.59 \mathrm{eV}$ that correspond to $\mathrm{C}=\mathrm{C}, \mathrm{C}-\mathrm{N}$ and $\mathrm{C}-\mathrm{N}$ bonding, while the N1s peak at $397.22 \mathrm{eV}$ is assigned to $\mathrm{C}=\mathrm{NH}-\mathrm{C}$ which is the pyridine-type $\left(\mathrm{N}_{\mathrm{py}}\right)$ in imidazole ring as the position of the basal plane of the square pyramidal. The C-NH-C or the pyrroletype interaction was observed at the binding energy of $398.42 \mathrm{eV}[25,26]$. In addition, the presence of peak at $398.91 \mathrm{eV}$ belongs to the positively charged nitrogen $\left(-\mathrm{N}^{+}\right)$, which originates from the pyridine-type nitrogen with the lone pair electrons transfer to $\mathrm{Cu}$ center atom. As shown in Figure 4, two strong peaks at 931.9 and $951.8 \mathrm{eV}$ are consistent with the literature data on $\mathrm{Cu} 2 \mathrm{p}_{3 / 2}$ and $\mathrm{Cu} 2 \mathrm{p}_{1 / 2}$, respectively [27]. These peaks can be attributed to the $\mathrm{Cu}^{2+}$ state in the $\left[\mathrm{Cu}(\mathrm{II})\left(\mathrm{C}_{3} \mathrm{~N}_{2} \mathrm{H}_{4}\right)_{4} \mathrm{Cl}\right]^{+}$ion. The states are different around $20 \mathrm{eV}$, which is close to the value reported in the literature [27]. The observed shakeup satellite peaks at 942 and $963 \mathrm{eV}$ are correspond to the paramagnetic chemical state of $\mathrm{Cu}(\mathrm{II})$ ion $[27,28]$. The binding energy of $\mathrm{Cl} 2 \mathrm{p}$ were obtained by deconvolution of line shape. Two Gaussian fitted peaks at 198 and $200 \mathrm{eV}$ can be assigned to $\mathrm{Cl} 2 \mathrm{p}_{3 / 2}$ and $\mathrm{Cl} 2 \mathrm{p}_{1 / 2}$, respectively. The almost half-intense Gaussian peak of $\mathrm{Cl} 2 \mathrm{p}_{1 / 2}$ with respect to $\mathrm{Cl} 2 \mathrm{p}_{3 / 2}$ also supported the fact that the $\mathrm{Cl}$ atoms are present in only one $\pi$-bonding of $\mathrm{Cu}-\mathrm{Cl}$ along the axial axis and another $\mathrm{Cl}$ atom act as counter anion to stabilize charge of $\left[\mathrm{Cu}\left(\mathrm{C}_{3} \mathrm{~N}_{2} \mathrm{H}_{4}\right)_{4} \mathrm{Cl}\right]^{+}$[28].
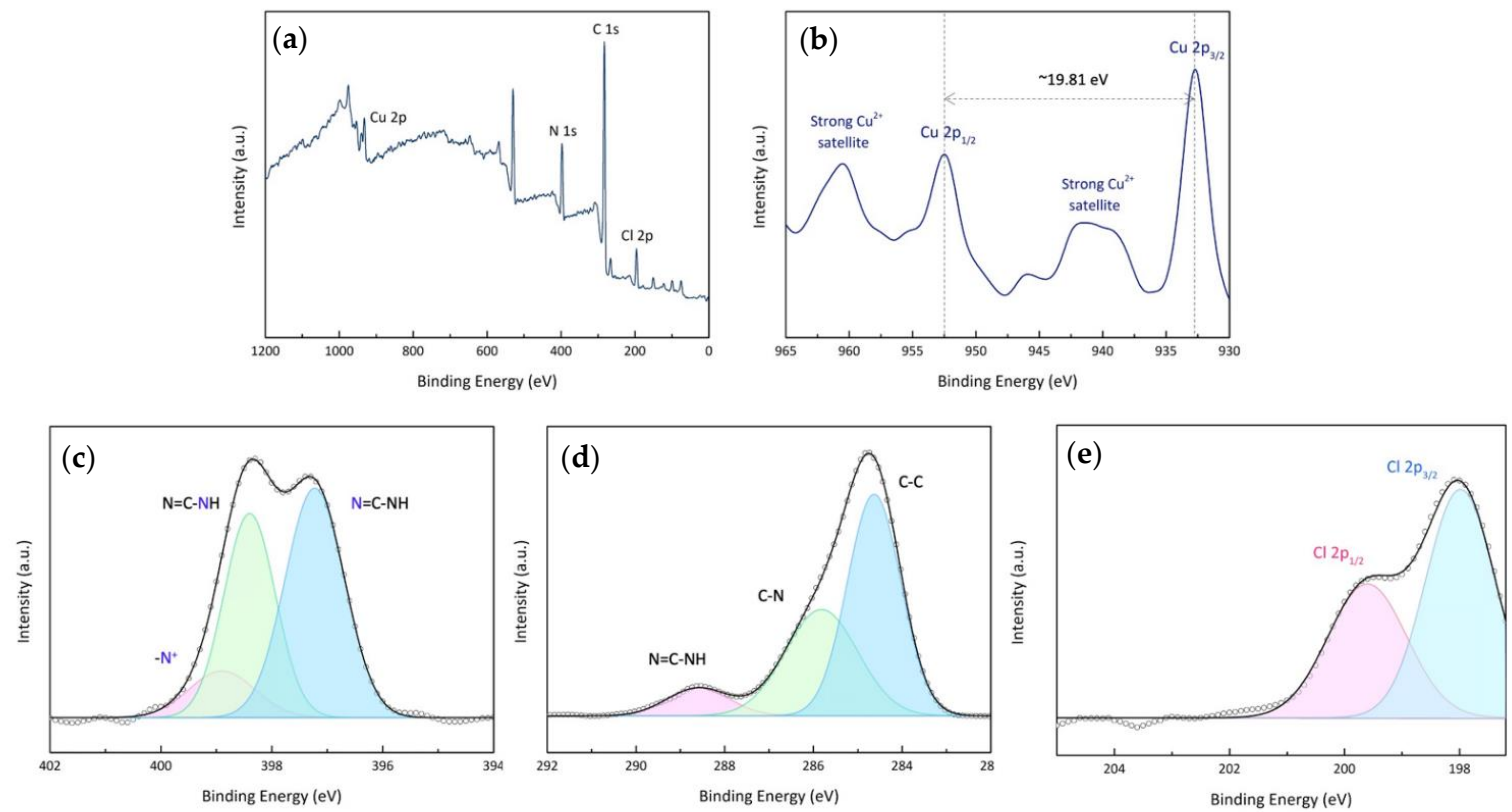

Figure 4. XPS spectra of $\mathrm{Cu}\left(\mathrm{C}_{3} \mathrm{~N}_{2} \mathrm{H}_{4}\right)_{4} \mathrm{Cl}_{2}$ showing wide spectrum and binding energy states in (a) wide scan, (b) $\mathrm{Cu} 2 \mathrm{p}$, (c) C1s, (d) N1s and (e) Cl2p orbitals. 


\subsection{FTIR, Element Analysis and TGA Thermogram}

The existence of imidazole ligands was confirmed by FTIR analysis. The strong bands in the range of 3500 to $2500 \mathrm{~cm}^{-1}$ signify the hydrogen bond interactions in the crystals. The $\mathrm{N}-\mathrm{H} \cdots \mathrm{Cl}$ intermolecular interaction can be observed at $3289 \mathrm{~cm}^{-1}$ corresponding to N-H stretching vibration of the imidazole ring to chloride [29], while the $1492 \mathrm{~cm}^{-1}$ band corresponds to the intermolecular hydrogen bond of $\mathrm{N}-\mathrm{H}$ bending vibration in the solid state. As seen in Figure 3, the C-H stretching vibrations were assigned at 3116 and $2949 \mathrm{~cm}^{-1}$. The N-H bending vibrations were assigned to the imidazole ring coupled from $C=C\left(1533 \mathrm{~cm}^{-1}\right)$ and $C=N\left(1425 \mathrm{~cm}^{-1}\right)$ stretching vibrations resulting in the overtone band at $2846 \mathrm{~cm}^{-1}$ as well [30]. The strong band at $1066 \mathrm{~cm}^{-1}$ corresponds to C-N stretching vibration. In the copper complexes, $\mathrm{C}-\mathrm{H}$ (out-of-plane) vibrations generate bands mainly at 862,794 and $773 \mathrm{~cm}^{-1}$, while N-H (out-of-plane) vibrations show at $613 \mathrm{~cm}^{-1}$. From FTIR spectrum, Cu-ligands' vibrations shown at $659 \mathrm{~cm}^{-1}$ result from the torsion vibrations of imidazole rings [30].

Further, the existence of imidazole as ligands in coordination complexes was investigated by thermogravimetric analysis, as shown in Figure 5. The TGA thermogram revealed the decomposition profile with two-step losses. The first weight loss appeared in the range of temperatures from 200 to $250{ }^{\circ} \mathrm{C}$ and was caused by a major loss of organic component, namely imidazole $\left(\mathrm{C}_{3} \mathrm{~N}_{2} \mathrm{H}_{4}\right)$ [31]. At higher temperature, the second-step decomposition is possibly the cause of deformation of inorganic components; copper and chloride undergo $85 \%$ weight loss at $650{ }^{\circ} \mathrm{C}$ [32]. It is noted that the remaining residues as shown in the tail of weight loss after the second step may correspond to the decomposition products present in the materials [33]. The element analysis was carried out by using the CHN analyzer to obtain the percentage amounts of carbon, nitrogen and hydrogen in coordination complexes.
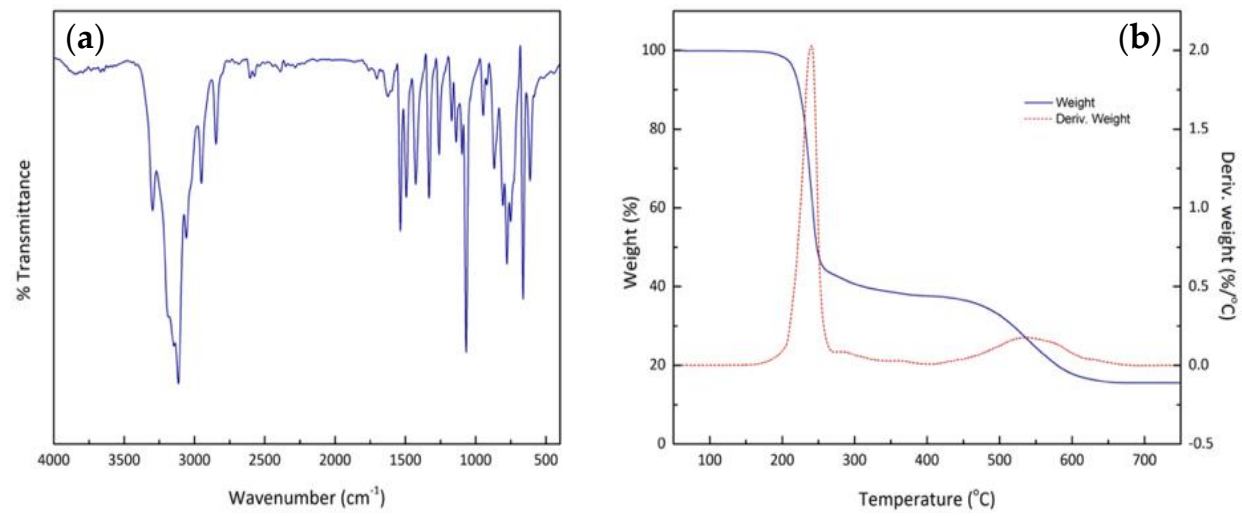

Figure 5. (a) FTIR spectra showing functional group characteristic peaks at different wavenumbers, and (b) TGA thermogram of $\mathrm{Cu}\left(\mathrm{C}_{3} \mathrm{~N}_{2} \mathrm{H}_{4}\right)_{4} \mathrm{Cl}_{2}$ coordinate complexes.

Then, The EMPA has allowed to determine the copper and chloride composition of coordination complexes. The elemental composition of the coordination complex is given as $\mathrm{C}, 35.14 ; \mathrm{H}, 3.94 ; \mathrm{N}, 27.32 ; \mathrm{Cu}, 15.49$; and $\mathrm{Cl}, 18.10 \%$.

\subsection{Fluorescence Spectra}

The fluorescence spectra of $\left[\mathrm{Cu}(\mathrm{II})\left(\mathrm{C}_{3} \mathrm{~N}_{2} \mathrm{H}_{4}\right)_{4} \mathrm{Cl}\right] \mathrm{Cl}$ coordination complexes were measured by a fluorescence spectrometer at ambient temperature. The synthesized complex was grounded and then treated by deionized water for $30 \mathrm{~min}$ in an ultrasonic bath to get the uniform aqueous suspension. The solution of complexes showed high stability in aqueous environment which is confirmed by XRD pattern as describe in Figure 3. Upon excitation wavelength at $330 \mathrm{~nm}$, the complex exhibits the strongest luminescence emission peak at $397 \mathrm{~nm}$ and gradually decreases in luminescent intensity when operating lower excitation wavelengths, as shown in Figure 6. 


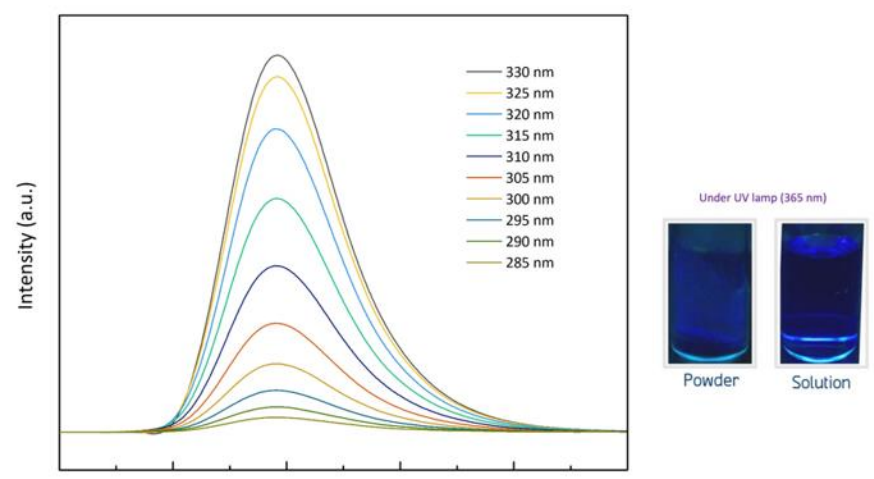

Figure 6. Emission spectra of copper coordinate complexes at each excitation wavelength.

In addition, the observed emission peak is contributed from the $\pi \rightarrow \pi^{*}$ transition of the ligand charge transfer [34]. Considering its structure, air stability, framework forming and stable luminescence in aqueous solution, the $\mathrm{Cu}\left(\mathrm{C}_{3} \mathrm{~N}_{2} \mathrm{H}_{4}\right)_{4} \mathrm{Cl}_{2}$ complex shows potential for luminescence $\mathrm{Cu}$-based sensors. The emission intensity quenching and enhancing behavior can be further studied for selective solvent or heavy metal ion in aqueous environment and developed to various applications

\section{Conclusions}

In summary, the $\mathrm{Cu}(\mathrm{II})$ square pyramidal coordination complex based on imidazole and chloride ligands was synthesized and studied on crystal and electronic structure levels. This copper(II) coordination complex $\mathrm{Cu}\left(\mathrm{C}_{3} \mathrm{~N}_{2} \mathrm{H}_{4}\right)_{4} \mathrm{Cl}_{2}$ geometry is not subject to the Jahn-Teller active. The intermolecular interaction of hydrogen bonds and $\pi \cdots \pi$ supramolecular interactions play a significant three-dimensional network-forming of a coordination complex. The absorbance spectra of complexes were obtained from aqueous solution of $\left[\mathrm{Cu}(\mathrm{II})\left(\mathrm{C}_{3} \mathrm{~N}_{2} \mathrm{H}_{4}\right)_{4} \mathrm{Cl}\right] \mathrm{Cl}$ coordination complex in the wavelength range of $200-800 \mathrm{~nm}$. The absorption band peaks at $627 \mathrm{~nm}$ were assigned to $\mathrm{d}-\mathrm{d}$ transition, showing $10 \mathrm{Dq}=15,949 \mathrm{~cm}^{-1}$ and crystal field stabilization energy $(\mathrm{CFSE})=0.6 \times 10 \mathrm{Dq}$ $=114.4 \mathrm{kJmol}^{-1}$, while the ligand-to-metal charge transfer (LMCT) of complexes displayed at $292 \mathrm{~nm}$. The intense luminescence band results from the ligand-to-metal charge transfer present at $397 \mathrm{~nm}$. The results contribute that the ligand charge transfer not only can reveal the presence $\mathrm{Cu}-\mathrm{Cl}$ coordination in aqueous solution but also plays a crucial role in the origin of luminescence at $397 \mathrm{~nm}$ emission wavelength. According to their structure, air stability, framework forming and stable luminescence in aqueous solution, the $\mathrm{Cu}\left(\mathrm{C}_{3} \mathrm{~N}_{2} \mathrm{H}_{4}\right)_{4} \mathrm{Cl}_{2}$ complex shows potential for luminescence $\mathrm{Cu}$-based sensors. The emission intensity quenching and enhancing behavior can be further studied for selective solvent or heavy metal ion in aqueous environment. Furthermore, the result described herein will be approached to new insight $\mathrm{Cu}^{2+}$-containing hybrid ligand frameworks which are enable for novel multifunctional metal-based system in material sciences.

Supplementary Materials: The following are available online at https:/ / www.mdpi.com/article/ 10.3390/nano11092281/s1. All crystallography data and CIF file of crystals are shown in the supplementary information. Table S1. Geometry intermolecular interaction for $[\mathrm{Cu}(\mathrm{II})(\mathrm{C} 3 \mathrm{~N} 2 \mathrm{H} 4) 4 \mathrm{Cl}] \mathrm{Cl}$ coordination complexes. Table S2. Bond Lengths for Chloridotetrakis(imidazole)copper(II) Chloride. Table S3. Fractional Atomic Coordinates $(\times 104)$ and Equivalent Isotropic Displacement Parameters $(\AA 2 \times 103)$ for Chloridotetrakis(imidazole)copper(II). Ueq is defined as $1 / 3$ of the trace of the orthogonalised UIJ tensor. Table S4. Anisotropic Displacement Parameters $(\AA 2 \times 103)$ for Chloridotetrakis(imidazole) copper(II) Chloride. The Anisotropic displacement factor exponent takes the form: $-2 \pi 2\left[h 2 a * 2 U 11+2 h k a * b^{*} U 12+\ldots\right.$ ]. Table S5. Bond Angles for Chlo-ridotetrakis(imidazole)copper(II) Chloride. Table S6. Hydrogen Atom Coordinates $(\AA \times 104)$ and Isotropic Displacement Parameters $(\AA 2 \times 103)$ for Chloridotetrakis(imidazole)copper(II) Chloride. Table S7. Presenting all functional groups of $\mathrm{Cu}(\mathrm{C} 3 \mathrm{~N} 2 \mathrm{H} 4) 4 \mathrm{Cl} 2$ via different wavenumbers. 
Author Contributions: S.C. was involved in all parts of this paper, including data analysis and writing. J.T. did the FTIR and TGA experiments. M.S. and H.M. planned the research, helped in the analysis of the results and edited the manuscript. All authors have read and agreed to the published version of the manuscript.

Funding: This research was funded by NSERC and ORF RE Funds.

Data Availability Statement: The data are available upon reasonable request from the corresponding author.

Acknowledgments: This research was supported by the Development and Promotion of Science and Technology Talent Project (DPST). The instruments were supported by The Petroleum and Petrochemical College, Chulalongkorn University and Department of Mechanical and Industrial Engineering, University of Toronto, Toronto, Canada.

Conflicts of Interest: The authors declare no conflict of interest.

\section{References}

1. Pascanu, V.; Miera, G.G.; Inge, A.K.; Martín-Matute, B. Metal-Organic Frameworks as Catalysts for Organic Synthesis: A Critical Perspective. J. Am. Chem. Soc. 2019, 141, 7223-7234. [CrossRef]

2. Li, Y.; Yang, R.T. Gas Adsorption and Storage in Metal-Organic Framework MOF-177. Langmuir 2007, 23, 12937-12944. [CrossRef]

3. Wang, Q.; Gao, Q.; Al-Enizi, A.M.; Nafady, A.; Ma, S. Recent advances in MOF-based photocatalysis: Environmental remediation under visible light. Inorg. Chem. Front. 2019, 7, 300-339. [CrossRef]

4. Downes, C.; Marinescu, S.C. Electrocatalytic Metal-Organic Frameworks for Energy Applications. ChemSusChem 2017, 10, 4374-4392. [CrossRef]

5. Nadar, S.; Rathod, V.K. Magnetic-metal organic framework (magnetic-MOF): A novel platform for enzyme immobilization and nanozyme applications. Int. J. Biol. Macromol. 2018, 120, 2293-2302. [CrossRef] [PubMed]

6. Chen, C.; Zhang, W.; Cong, J.; Cheng, M.; Zhang, B.; Chen, H.; Liu, P.; Li, R.; Safdari, M.; Kloo, L.; et al. Cu(II) Complexes as p-Type Dopants in Efficient Perovskite Solar Cells. ACS Energy Lett. 2017, 2, 497-503. [CrossRef]

7. Shu, Y.; Hao, J.-N.; Niu, D.; Li, Y. A smart luminescent metal-organic framework-based logic system for simultaneous analysis of copper ions and hydrogen sulfide. J. Mater. Chem. C 2020, 8, 8635-8642. [CrossRef]

8. Pearson, R.G. Hard and Soft Acids and Bases. J. Am. Chem. Soc. 1963, 85, 3533-3539. [CrossRef]

9. Persson, I.; Penner-Hahn, J.; Hodgson, K.O. An EXAFS spectroscopic study of solvates of copper(I) and copper(II) in acetonitrile, dimethyl sulfoxide, pyridine, and tetrahydrothiophene solutions and a large-angle x-ray scattering study of the copper(II) acetonitrile solvate in solution. Inorg. Chem. 1993, 32, 2497-2501. [CrossRef]

10. Pasquarello, A.; Petri, I.; Salmon, P.S.; Parisel, O.; Car, R.; Tóth, E.; Powell, D.H.; Fischer, H.E.; Helm, L.; Merbach, A.E. First Solvation Shell of the $\mathrm{Cu}(\mathrm{II})$ Aqua Ion: Evidence for Fivefold Coordination. Science 2001, 291, 856-859. [CrossRef]

11. Frank, P.; Benfatto, M.; Hedman, B.; Hodgson, K.O. The X-ray Absorption Spectroscopic Model of the Copper(II) Imidazole Complex Ion in Liquid Aqueous Solution: A Strongly Solvated Square Pyramid. Inorg. Chem. 2012, 51, 2086-2096. [CrossRef]

12. Sadaoui-Kacel, S.; Zaater, S.; Bensouilah, N.; Djebbar, S. Novel repaglinide complexes with manganese(II), iron(III), copper(II) and zinc(II): Spectroscopic, DFT characterization and electrochemical behaviour. J. Struct. Chem. 2016, 57, 1519-1530. [CrossRef]

13. Jahn, H.A.; Teller, E. Stability of polyatomic molecules in degenerate electronic states-I-Orbital degeneracy. Proc. R. Soc. Lond. $1937,161,220-235$.

14. Reinen, D.; Atanasov, M.; Köhler, P.; Babel, D. Jahn-Teller coupling and the influence of strain in $\mathrm{T}_{\mathrm{g}}$ and $\mathrm{E}_{\mathrm{g}}$ ground and excited states-A ligand field and DFT study on halide $\mathrm{M}^{\mathrm{III}} \mathrm{X}_{6}$ model complexes $\left[\mathrm{M}=\mathrm{Ti}^{\mathrm{III}}-\mathrm{Cu}^{\mathrm{III}} ; \mathrm{X}=\mathrm{F}^{-}, \mathrm{Cl}^{-}\right]$. Coord. Chem. Rev. 2010, 254, 2703-2754. [CrossRef]

15. Bin Li, T.; Hu, Y.L.; Li, J.K.; He, G.F. Chloridotetrakis (imidazole) copper (II) chloride. Acta Crystallogr. Sect. E Struct. Rep. Online 2007, 63, m2536.

16. Jian, F.F.; Tong, Y.P.; Xiao, L.H.; Wang, Q.X.; Jiao, K. Structure and thermal properties of transition metal imidazole chloride. Chin. J. Struct. Chem. 2004, 23, 979-984.

17. Pato-Doldán, B.; Aguirre, L.C.G.; Bermúdez-García, J.M.; Sánchez-Andújar, M.; Fondado, A.F.; Mira, J.; Castro-García, S.; Señarís-Rodríguez, M.A. Coexistence of magnetic and electrical order in the new perovskite-like $\left(\mathrm{C}_{3} \mathrm{~N}_{2} \mathrm{H}_{5}\right)\left[\mathrm{Mn}(\mathrm{HCOO})_{3}\right]$ formate. RSC Adv. 2013, 3, 22404-22411. [CrossRef]

18. Sundberg, R.J.; Martin, R.B. Interactions of histidine and other imidazole derivatives with transition metal ions in chemical and biological systems. Chem. Rev. 1974, 74, 471-517. [CrossRef]

19. Otieno, T.; Hatfield, M.J.; Asher, S.L.; McMullin, A.I.; Patrick, B.O.; Parkin, S. Structures Of Pentakis-(Imidazole)Copper(II) Hexafluoroarsenate Monohydrate And Chlorotetrakis-(Imidazole)Copper(II) Chloride. Synth. React. Inorg. Met. Chem. 2001, 31, 1587-1598. [CrossRef]

20. Halcrow, M.A. Jahn-Teller distortions in transition metal compounds, and their importance in functional molecular and inorganic materials. Chem. Soc. Rev. 2013, 42, 1784-1795. [CrossRef] 
21. House, J.E. Chapter 17-Ligand fields and molecular orbitals. In Inorganic Chemistry, 3rd ed.; House, J.E., Ed.; Academic Press: Cambridge, MA, USA, 2020; pp. 687-715.

22. Olshin, P.; Myasnikova, O.S.; Kashina, M.; Gorbunov, A.O.; Bogachev, N.; Kompanets, V.O.; Chekalin, S.V.; Pulkin, S.A.; Kochemirovsky, V.A.; Skripkin, M.Y.; et al. The electronic spectra and the structures of the individual copper(II) chloride and bromide complexes in acetonitrile according to steady-state absorption spectroscopy and DFT/TD-DFT calculations. Chem. Phys. 2018, 503, 14-19. [CrossRef]

23. Cheruzel, L.E.; Cecil, M.R.; Edison, S.E.; Mashuta, M.; Baldwin, M.; Buchanan, R.M. Structural and Spectroscopic Characterization of Copper(II) Complexes of a New Bisamide Functionalized Imidazole Tripod and Evidence for the Formation of a Mononuclear End-On $\mathrm{Cu}-\mathrm{OOH}$ Species. Inorg. Chem. 2006, 45, 3191-3202. [CrossRef]

24. Mereshchenko, A.S.; Olshin, P.; Karimov, A.M.; Skripkin, M.; Burkov, K.A.; Tveryanovich, Y.; Tarnovsky, A.N. Photochemistry of copper(II) chlorocomplexes in acetonitrile: Trapping the ligand-to-metal charge transfer excited state relaxations pathways. Chem. Phys. Lett. 2014, 615, 105-110. [CrossRef]

25. Bhargava, G.; Ramanarayanan, T.; Bernasek, S.L. Imidazole-Fe Interaction in an Aqueous Chloride Medium: Effect of Cathodic Reduction of the Native Oxide. Langmuir 2009, 26, 215-219. [CrossRef] [PubMed]

26. Kostko, O.; Xu, B.; Ahmed, M. Local electronic structure of histidine in aqueous solution. Phys. Chem. Chem. Phys. 2021, 23, 8847-8853. [CrossRef] [PubMed]

27. Adhikari, S.; Sarkar, D.; Madras, G. Hierarchical Design of CuS Architectures for Visible Light Photocatalysis of 4-Chlorophenol. ACS Omega 2017, 2, 4009-4021. [CrossRef]

28. Drolet, D.P.; Manuta, D.M.; Lees, A.J.; Katnani, A.; Coyle, G.J. FT-IR and XPS study of copper(II) complexes of imidazole and benzimidazole. Inorganic. Chim. Acta 1988, 146, 173-180. [CrossRef]

29. Morzyk-Ociepa, B.; Różycka-Sokołowska, E.; Michalska, D. Revised crystal and molecular structure, FT-IR spectra and DFT studies of chlorotetrakis(imidazole)copper(II) chloride. J. Mol. Struct. 2012, 1028, 49-56. [CrossRef]

30. Majoube, M.; Vergoten, G. Assignment of normal modes for imidazole on the basis of 3-21G and 4-21G Ab Initio Force Fields. J. Mol. Struct. 1992, 266, 345-352. [CrossRef]

31. Tritt-Goc, J.; Jankowska, I.; Pogorzelec-Glaser, K.; Pankiewicz, R.; Ławniczak, P. Imidazole-doped nanocrystalline cellulose solid proton conductor: Synthesis, thermal properties, and conductivity. Cellulose 2017, 25, 281-291. [CrossRef]

32. Cortecchia, D.; Dewi, H.A.; Yin, J.; Bruno, A.; Chen, S.; Baikie, T.; Boix, P.P.; Gratzel, M.; Mhaisalkar, S.; Soci, C.; et al. Lead-Free $\mathrm{MA}_{2} \mathrm{CuCl}_{\mathrm{x}} \mathrm{Br}_{4-\mathrm{x}}$ Hybrid Perovskites. Inorg. Chem. 2016, 55, 1044-1052. [CrossRef] [PubMed]

33. Dualeh, A.; Gao, P.; Seok, S.I.; Nazeeruddin, M.K.; Grätzel, M. Thermal Behavior of Methylammonium Lead-Trihalide Perovskite Photovoltaic Light Harvesters. Chem. Mater. 2014, 26, 6160-6164. [CrossRef]

34. Wu, W.; Xie, J.; Xie, D. Two copper complexes with imidazole ligands: Syntheses, crystal structures and fluorescence. Russ. J. Inorg. Chem. 2010, 55, 384-389. [CrossRef] 